Article

\title{
Sustainable Development Goals (SDGs): Assessing the Contribution of Higher Education Programmes
}

\author{
Vasiliki Kioupi and Nikolaos Voulvoulis *(1) \\ Centre for Environmental Policy, Imperial College London, London SW7 1NE, UK; v.kioupi17@imperial.ac.uk \\ * Correspondence: n.voulvoulis@imperial.ac.uk; Tel.: +44-2075-947-459
}

Received: 14 July 2020; Accepted: 15 August 2020; Published: 19 August 2020

\begin{abstract}
Universities are engines of societal transformation and can nurture future citizens and navigate them towards sustainability through their educational programmes. Here, we developed an assessment framework for educational institutions to evaluate the contribution of their educational programmes to sustainability by reviewing the alignment of their intended learning outcomes to the enabling conditions for a vision of sustainability based on the Sustainable Development Goals (SDGs). The tool is based on a systemic grouping of the SDGs into eight sustainability attributes, namely, Safe Operating Space, Just Operating Space, Resilient Sustainable Behaviours, Alternative Economic Models, Health and Wellbeing, Collaboration, Diversity and Inclusion, and Transparency and Governance, and uses a word code developed specifically for each sustainability attribute to assess the coverage of the SDGs in master's programmes' learning outcomes. The tool uses multi-criteria analysis to compare and rank programmes according to the alignment of their learning outcomes to the sustainability attributes and their contribution to sustainability. It was first tested using data from a University's eighteen master's programmes on a range of subjects and subsequently applied to compare forty UK and European master's programmes focusing on environment and sustainability. Findings demonstrate that even environmental programmes face some important gaps related to health, wellbeing, diversity, inclusion, and collaboration, amongst others, and reinforce the need for all universities to understand the contribution of their programmes to sustainability. The application of the tool can generate empirical evidence on the effectiveness of university programmes and establish a strong argument regarding the potential of education as a tool for achieving the SDGs.
\end{abstract}

Keywords: Sustainable Development Goals (SDGs); assessment framework; learning outcomes; sustainability attributes; master's programmes

\section{Introduction}

The ongoing discourse about sustainability and the realisation of the 2030 Agenda of Sustainable Development Goals (SDGs) looks to balance economic growth, social equity, and environmental protection inclusively for developed and developing countries, leaving no one behind. The SDG framework places education in a central role as a catalyst for transformational change [1]. Universities can play an important role in the realisation of the SDGs, as they have long been powerful drivers of global, national, and local innovation, economic development, and societal wellbeing [2]. They can help to shape new ways of educating global citizens and delivering knowledge and innovation into society. They can contribute to the SDGs through their learning and teaching activities, research, organisational governance, culture and operations, and external leadership [3] and are expected to actively engage in the process. For example, a new league table measuring the success of Higher Education (HE) Institutions in delivering the SDGs was introduced in 2019 (Times Higher Education (THE) University Impact Rankings). This included metrics based on 11 of the SDGs, with institutions 
submitting data on as many or as few of those as they wished but with mandatory reporting on SDG 17: Partnerships for the Goals, which was included in the overall table [4].

Among the many contributions Universities can make to sustainability, education has the greatest potential, and this is reflected in Sustainable Development Goal 4, Quality Education. Higher Education is mentioned in target 4.3, which aims to "by 2030, ensure equal access for all women and men to affordable and quality technical, vocational, and tertiary education, including university". Higher Education also forms an important part of other goals related to poverty (SDG1), health and wellbeing (SDG3), gender equality (SDG5) governance, decent work and economic growth (SDG8), responsible consumption and production (SDG12), climate change (SDG13), and peace, justice, and strong institutions (SDG16). The Education 2030 Framework for Action (EFA) necessitates reform of the HE sector through international agreements that establish and regulate teaching and learning activities, so that they become aligned with sustainable development (SD). Furthermore, this roadmap intends to leverage the power of digital tools, open educational resources, and online learning to promote access, equity, quality, and relevance. Target 4.7 explicitly mentions education for sustainable development (ESD) as the kind of education that can empower learners with important knowledge, skills, and attitudes to pursue sustainability [5].

While there is still debate on whether ESD should be offered as a stand-alone course or incorporated in all educational offerings, the number of university programmes that explicitly identify themselves and their graduates as representing the field of sustainability has increased globally [6], as well as the number of programmes that incorporate aspects of sustainability within an existing discipline [7]. A recent bibliometric study showed that sustainability education is booming in universities globally, with special focus on students' attitudes, highlighting that research in the field is descriptive rather than empirical [8]. For example in the US, HE programmes explicitly focusing on sustainability increased to over 140 in 2012, from 1 in 2006 [9]. In the UK, 91\% of university students would like to see SD incorporated in their university, $70 \%$ agree that Sustainability should be incorporated in all courses, but only $17 \%$ think that their university does a very good job related to SD [10]. A recent study also showed that the knowledge level of university students regarding the SDGs is low and that much more can be done by universities to change this [11].

Although a number of universities have employed effective pedagogies for ESD [12], and several have defined sustainability-related educational outcomes for their programmes [13], little work has been done to evaluate university offerings in sustainability education, such that their quality, curricular content, and effectiveness are largely unknown. The most comprehensive sustainability curriculum assessments have been done for Australia, where authors [14-16] evaluated the required courses for that country's environmental programmes more generally, including nine programmes granting degrees in sustainability. There have also been reviews that considered the presence of sustainability concepts within specific disciplines in certain geographic areas, for example engineering in Europe [17] and the built environment in Asia-Pacific [18]. Another review of curriculum contents of undergraduate and master's programmes related to sustainability found great divergence in the content of those courses and also low degrees of integration between natural and social sciences [6]. Recent research indicates that universities are making progress towards integrating the SDGs into curricula, but that this is done in an ad-hoc way and application is not guaranteed, mainly because of the broad focus and complexity of integrating the SDGs into teaching [19]. To deal with this complexity, it is important to look at the contribution of university educational programmes to sustainability from a systems perspective.

Universities can be engines of societal transformation. They nurture the future leaders, professionals, and citizens and can navigate them towards sustainability through their educational programmes. The role of HE in the realisation of the SDGs is therefore its contribution to the transformational transition to sustainability. Sustainability is envisioned as a system state that our society is constantly trying to define and reach, guided by the SDGs, and the contribution of education is thus to create the enabling conditions for this vision to emerge [20]. This will require defining first the competences, i.e., the knowledge, skills, behaviours, and attitudes, that learners need to 
develop to realise such a state, and then the curricula, pedagogies, educator training programmes, and learning environments at each level of their educational offerings. While there are generic lists of competences related to educational programmes for sustainability, a more appropriate selection should be based on a local vision of sustainability. Educational communities therefore need to form their own sustainability vision of the future in order to define the sustainability competences delivered by their programmes and to put in place the right pedagogies, curricula, and assessments to align with the enabling conditions for such vision to emerge [21]. Explicit evaluation of the extent to which their programmes align with SD allows Universities to understand the contribution of their educational offerings to achieving the SDGs in a more systemic way.

University programmes have learning outcomes (LOs) that define what graduates should know and be able to do at the end of their studies. Clear intended LOs are a key component of good programme and unit planning and assessment for students. The Quality Assurance Agency (QAA) UK Quality Code for HE: Learning and teaching [21] gives clear guidance on the purpose and design of LOs: Universities need to ensure that the intended LOs of a programme are explicitly reflected in the intended LOs of its constituent units, and that all learning and teaching activities and associated resources provide every student with an equal and effective opportunity to achieve these outcomes. Understanding the alignment of a university programme's LOs or the competences the learners need to develop allows academic staff to find areas of sustainability that are over- or underrepresented in the curriculum, map gaps, and take decisions to improve them.

Here, therefore, we develop an assessment framework for educational institutions to evaluate the contribution of their educational programmes to sustainability by reviewing their intended LOs-unless programmes have already established the competences they target, in which case those can be used in the assessment. The framework takes a holistic and systemic approach based on the sustainability attributes required for the SDGs to be realised, avoiding the perils of having to evaluate the integration of each SDG in the programmes' intended LOs separately. Its application can generate empirical evidence on the effectiveness of university programmes and establish a strong argument regarding the potential of education as a tool for achieving the SDGs.

\section{Materials and Methods}

\subsection{The Assessment Framework Methodology}

The assessment process is based on a systemic framework that uses the SDGs to develop a vision of a future sustainable society and the enabling conditions for such vision to emerge [20]. It evaluates the alignment of a programme's intended LOs to these attributes as an indication of its contribution to sustainability. It allows even for assessing programmes that do not target sustainability directly, in case they deliver competences that contribute to the emergence of sustainability. The sustainability attributes are grouped as enabling conditions for a vision of sustainability related to the SDGs (Table 1). These eight groups have been constructed by grouping the SDGs into categories defined by major systemic attributes and enabling conditions, namely: achieving the safe operating space (refers to maintaining ecological integrity and not transgressing crucial planetary boundaries conditions), achieving the just operating space (includes the social foundation of justice, equity, and equality for all, now and in the future (intergenerational dimension) under conditions empowering them to lead fulfilling lives), transparency and responsible governance, health and wellbeing, diversity and inclusion, resilient sustainable behaviours, and collaboration (for partnerships needed between many actors of civic society that lead to innovation), as well as an economic approach that is not short-sighted and ensures that humanity operates within the safe and just space to promote natural and human wellbeing [20]. 
Table 1. The sustainability attributes used for assessing the alignment of university programmes to sustainability.

\begin{tabular}{|c|c|}
\hline Safe Operating Space SOS & Collaboration COL \\
\hline $\begin{array}{l}\text { Living well within planetary boundaries, with } \\
\text { reference to the environmental processes that render } \\
\text { the earth habitable by life such as: biosphere integrity, } \\
\text { land-system change, freshwater use, biogeochemical } \\
\text { flows, ocean acidification, atmospheric aerosol } \\
\text { loading, stratospheric ozone depletion, climate } \\
\text { change, novel entities (emerging processes). }\end{array}$ & $\begin{array}{l}\text { Reference to the conditions that foster competences } \\
\text { such as: working in inter/trans-disciplinary teams, } \\
\text { empathy, active listening, appreciating the views of } \\
\text { others, resolving conflict, sharing responsibility for } \\
\text { task completion, encouraging and motivating self and } \\
\text { others to participate and effective communication } \\
\text { with a wide variety of audiences. }\end{array}$ \\
\hline Just Operating Place JOS & Alternative Economic Models AEM \\
\hline $\begin{array}{l}\text { Inter- and intra-generational equity with reference to } \\
\text { the conditions that help humanity thrive now and in } \\
\text { the future: social justice and equity, equality, human } \\
\text { rights, peace and non-violence, and active } \\
\text { participation in social life. Social systems that allow } \\
\text { people to live fulfilling lives and education provision } \\
\text { that helps citizens realise their potential. }\end{array}$ & $\begin{array}{l}\text { Economic models that deviate from aiming solely at } \\
\text { economic growth, which jeopardises the safe and just } \\
\text { operating space, such as those that mimic nature, } \\
\text { focus on systemic change, involve the use of existing } \\
\text { or novel technology, promote equity, minimise waste, } \\
\text { redefine the meaning of work and growth, preserve } \\
\text { natural resources, and lift people out of poverty. }\end{array}$ \\
\hline Resilient Sustainable Behaviours RSB & Diversity and Inclusion DI \\
\hline $\begin{array}{l}\text { The ethical conditions that enable long-term } \\
\text { sustainability: values, norms, behaviours and } \\
\text { attitudes related to doing the right thing, } \\
\text { responsibility for choices and actions, solidarity, } \\
\text { compassion, tolerance, and respect for all life. Critical } \\
\text { inquiry into challenges and analysis/evaluation of } \\
\text { available viewpoints on the issues faced. Ability to } \\
\text { view issues from multiple perspectives } \\
\text { (interdisciplinary approach) and develop } \\
\text { holistic solutions. }\end{array}$ & $\begin{array}{l}\text { This includes biodiversity (genetic, species, } \\
\text { landscapes, and ecosystems diversity), diversity of } \\
\text { cultures and disciplines, examination of various } \\
\text { worldviews and perspectives, gender, ethnicity, and } \\
\text { disability, as well as their integration, interactions, } \\
\text { and interdependence from a systems view. }\end{array}$ \\
\hline Health and Wellbeing HW & and Governance TG \\
\hline $\begin{array}{l}\text { Reference to the social, environmental, and cultural } \\
\text { conditions that can enhance or diminish health and } \\
\text { wellbeing: prevention of disease, sound mental } \\
\text { health, healthcare systems, social security, water, air } \\
\text { and food quality, transport safety, maternal and child } \\
\text { health, access to healthcare services, sense of } \\
\text { community, mindfulness, and effective health and } \\
\text { wellbeing management. }\end{array}$ & $\begin{array}{l}\text { Open access to data and procedures at all levels (local, } \\
\text { regional, national, and international), stakeholder } \\
\text { engagement, public participation in decision-making, } \\
\text { democratic principles, policies regarding use of data, } \\
\text { and regulations regarding sharing them. }\end{array}$ \\
\hline
\end{tabular}

To evaluate the alignment of a programme's intended LOs to these attributes, we have developed a simple tool that uses textual analysis for the descriptors of LOs and evaluates their alignment to each of these eight sustainability attributes using a word code. The word code was produced in NVIVO 12 software by (1) identifying words that constitute the accepted and commonly used scientific language for each attribute $[1,22-45]$; (2) by analysing the texts of the benchmark statements provided by the QAA for HE in the UK for specific university subjects that match the sustainable society attributes we systemically selected; and (3) specifically for the Diversity and Inclusion word code, we analysed Advance HE's reports regarding Athena SWAN [46], Race Equality Charters [47], and the Equality and Diversity in Learning and Teaching in HE [48].

Regarding the QAA documents, we used the following Subject Benchmark Statements:

1. Education for Sustainable Development (ESD) Graduate Outcomes

2. Earth Sciences, Environmental Sciences and Environmental Studies

3. Sociology

4. Social Policy

5. Economics

6. Business and Management

7. Health studies 
8. Politics and International relations

9. Law

10. Collaboration statements from all the above texts

By analysing the parts of the documents referring to the defining principles, nature and extent and specific LOs in terms of subject specific and generic knowledge, skills, and attributes of graduates for each type of course, we made associations between the benchmark statements and the sustainable society attributes. We then ran word frequency queries in the above-mentioned benchmark statements and enriched our word codes (Table 2). We did the same with the Equality Challenge Unit documents for DI.

Table 2. The developed word code per sustainability attribute.

\begin{tabular}{|c|c|}
\hline $\begin{array}{l}\text { SOS|Source = Earth Sciences, Environmental } \\
\text { Sciences and Environmental Studies }\end{array}$ & $\begin{array}{l}\text { COL|Source = Collaboration Statements from All } \\
\text { Benchmark Documents }\end{array}$ \\
\hline $\begin{array}{l}\text { Global; Boundary; Earth; Boundaries; Climate; } \\
\text { Planetary; Land; Ocean; Regional; State; Biodiversity; } \\
\text { wildlife; Thresholds; nexus; CO2; Ecosystems; } \\
\text { Environmental; Global-Change; Climate-Change; } \\
\text { Atmospheric; Resilience; Safe; Soil; Freshwater; } \\
\text { Ozone; Variable; Ecology; Ecological; Geology; } \\
\text { Geological; geo; Hydrology; Hydrological; Effects; } \\
\text { Marine; Uncertainty; uncertain; Concentration; } \\
\text { Threshold; Ecosystem; Atmosphere; Flows; Impacts; } \\
\text { Species; Nitrogen; Chemical; biological; Biosphere; } \\
\text { geosphere; hydrosphere; Phosphorus; Pollution; air; } \\
\text { Acidification; Anthropogenic; Cycle; Extinction; } \\
\text { Space; Chemicals; Industrial; Zone; Holocene; } \\
\text { Anthropocene; Climate; Stratospheric; Aerosol; } \\
\text { Integrity; interactions; Biogeochemical; Greenhouse; } \\
\text { Gas; Gases; Emission; Emissions; Impact; } \\
\text { Uncertainties; wicked; biophysical; constraint; } \\
\text { constraints; safety; mitigation; } \\
\text { adaptation; complexity. }\end{array}$ & $\begin{array}{l}\text { Group; collaboration; empathy; cooperation; } \\
\text { cooperative; together; mutual; joint; jointly; shared; } \\
\text { loyalty; member; participant; allocation; } \\
\text { communication; communicative; communicate; } \\
\text { encourage; motivate; resolve; conflict; task; listen; } \\
\text { listening; motivate; team; teamwork; judgement; } \\
\text { crowd; participatory; conversation; discussion; } \\
\text { activity; negotiation; consensus; allocate; dominance; } \\
\text { dominate; coordination; coordinate; team-dynamics; } \\
\text { group-dynamics; transdisciplinarity; } \\
\text { multidisciplinary; multidisciplinarity; disciplinary; } \\
\text { transdisciplinary; disciplines; collaborate; } \\
\text { stakeholder; interpersonal. }\end{array}$ \\
\hline JOS $\mid$ Source = Sociology and Social Policy & $\begin{array}{l}\text { AEM } \mid \text { Source = Economics and Business and } \\
\text { Management }\end{array}$ \\
\hline $\begin{array}{l}\text { Social; socially; community; intergenerational; } \\
\text { intragenerational; social-equity; peace; } \\
\text { underdeveloped; industrialised; developing; active; } \\
\text { humanity; human; participation; society; Justice; } \\
\text { women; just; transformation; race; minority; } \\
\text { minorities; North; South; Ethnic; ethnicity; regional; } \\
\text { gender; foundation; peace; poverty; Non-violence; } \\
\text { conflict; inequality; inequalities; future; ceiling; } \\
\text { population; changing; accessed; access; discussion; } \\
\text { income; men; need; rights; education; transition; } \\
\text { power; conditions; wealth; Security; doughnut; } \\
\text { deprivation; communities; households; distribution; } \\
\text { children; violence; deprived; status; food; water; } \\
\text { energy; jobs; employment; voice; resilient; } \\
\text { unemployment; gap; people; concept; dialogue; fair; } \\
\text { common; exploitation; population-dynamics; } \\
\text { community-dynamics. }\end{array}$ & $\begin{array}{l}\text { Regenerative; circular; re-use; reuse; remanufacture; } \\
\text { remanufacturing; recycle; recycling; economy; } \\
\text { economic; consumption; financial; indicator; business; } \\
\text { entrepreneurship; profit; alternative; model; growth; } \\
\text { waste; tax; taxation; product; products; production; } \\
\text { materials; efficiency; services; technology; } \\
\text { technological; balance; lifecycle; life-cycle; innovation; } \\
\text { innovative; technologies; cost. }\end{array}$ \\
\hline
\end{tabular}


Table 2. Cont.

\begin{tabular}{|c|c|}
\hline $\begin{array}{l}\text { RSB } \mid \text { Source = Education for Sustainable } \\
\text { Development Graduate Outcomes }\end{array}$ & $\begin{array}{l}\text { DI|Source = Advance HE Athena SWAN and Race } \\
\text { Equality Charters, Biodiversity IPBES, FAO, WWF }\end{array}$ \\
\hline $\begin{array}{l}\text { Sustainable; sustainability; competencies; } \\
\text { competences; competence; thinking; normative; } \\
\text { critical; norms; values; value; norm; competency; } \\
\text { behaviour; ability; self-confidence; ethics; ethical; } \\
\text { moral; ethic; challenges; challenge; educational; socio; } \\
\text { motivations; motivation; informal; injunctive; } \\
\text { perspective; responsibility; responsibilities; actions; } \\
\text { action; context; contexts; assessment; citizen; } \\
\text { citizenship; capacity; capability; incentive; argument; } \\
\text { motivation; motive; choice; choices; compassion; } \\
\text { tolerance; tolerant; solidarity; respect; behavioural; } \\
\text { attitude; attitudinal; engage; commit RE engagement; } \\
\text { commitment; belief; beliefs; management; planning; } \\
\text { virtue; solutions; interdisciplinarity; interdisciplinary; } \\
\text { reflection; stewardship. }\end{array}$ & $\begin{array}{l}\text { Diversity; inclusion; inclusivity; inclusive; bias; } \\
\text { biases; gender-identity; stereotype; stereotypes; } \\
\text { ethnicity; ethnicities; belonging; racial; variety; } \\
\text { stereotypical; non-gender; diverse; socioeconomic; } \\
\text { domination; disability; disabilities; ethos; } \\
\text { intersectionality; characteristic; protected; BME; } \\
\text { BAME; role-model; discrimination; racism; } \\
\text { anti-racism; fairness; parity; underrepresented; } \\
\text { marginalised; genetic; conservation; loss; } \\
\text { intercultural; multicultural; racist; inequity; anti. }\end{array}$ \\
\hline HW $\mid$ Source $=$ Health Studies & $\begin{array}{l}\text { TG|Source = Politics and International Relations } \\
\text { and Law }\end{array}$ \\
\hline $\begin{array}{l}\text { Wellbeing; well-being; welfare; culture; cultural; life; } \\
\text { health; quality; collective; happiness; index; creative; } \\
\text { intuitive; history; historical; cognitive; license; lives; } \\
\text { mental; mind; worldview; equitable; emotion; } \\
\text { emotional; cohesion; identity; character; care; western; } \\
\text { relationships; relational; holistic; satisfaction; } \\
\text { consciousness; empathy; feedback; connections; } \\
\text { interconnections; prosperity; joy; positive; negative; } \\
\text { vision; pattern; thrive; psychological; psychology; } \\
\text { mindfulness; illness; disease. }\end{array}$ & $\begin{array}{l}\text { Transparency; open; open-ended; openness; } \\
\text { open-mindedness; open-minded; open-access; } \\
\text { governance; policy; legal; laws; law; government; } \\
\text { political; framework; transparent; integration; } \\
\text { democracy; democratic; regulations; regulation; } \\
\text { interdependence; procedures; systemic; leadership; } \\
\text { strategy; strategic; evidence; decision-making; } \\
\text { regulatory; international; transnational; accessibility. }\end{array}$ \\
\hline
\end{tabular}

Multi Criteria Analysis (MCA) was then used to evaluate and compare the performance of different courses across all eight sustainability attributes, with the multicriteria evaluation performed through the analytic hierarchical process (AHP). In general, the higher the score, the better the coverage of the course within the concerned attribute. In order to rank the courses in terms of their overall performance across all the criteria, differences are expressed in a condensed way by means of paired comparisons [49]. A positive score implies better alignment of one programme in relation to another while a negative value implies the opposite. A dominance measure of 0 implies an indifference between the compared courses. The method allows for weighting these dominance measures with the aggregated weights of the constituent criteria for the overall dominance score per course to be calculated (although attributes had the same weight in this case). We assumed that all attributes were equally important, and as a result were given the same weight. The final score represents the degree to which an alternative is more or less aligned to sustainability compared to the rest, based on the number of criteria on which it outperforms the rest. This method is preferred to using the sum or average value of the word code coverage for each attribute, as it offers a more holistic view of how courses compare across all attributes [50]. A simple linear additive evaluation model would not be appropriate, as the criteria are not mutually preference independent, and the scores derived from the word codes do not represent absolute values with defined ranges, but act as indicators of comparative performance. For example, courses with very high scores in a few attributes will not rank higher than courses performing better across all attributes. University programmes can, therefore, be ranked according to their contribution to sustainability, by comparing the alignment of their intended LOs to these attributes.

To test the tool, 18 master's programmes across several subjects (engineering, environmental policy, science communication, physics, chemistry, computing, mathematics, medicine and life sciences) 
from the same HE Institution were compared by evaluating the alignment of their LOs across the eight attributes, considering their disciplinary focus as an indicator of sustainability coverage (Table 3).

Table 3. Performance of the 18 Imperial College London master's courses' LOs across the eight sustainability attributes using the word codes developed.

\begin{tabular}{|c|c|c|c|c|c|c|c|c|}
\hline Master's Programmes & SOS & JOS & RSB & AEM & HW & COL & DI & TG \\
\hline MSc Environmental Technology & 4.78 & 1.24 & 5.87 & 1.12 & 0.31 & 1.65 & 0.12 & 1.87 \\
\hline MRes Ecosystems and Environmental Change & 3.66 & 0.38 & 2.25 & 0.38 & 0.00 & 2.14 & 0.42 & 2.79 \\
\hline MSc Advanced materials for Sustainable Infrastructure & 2.16 & 0.39 & 2.03 & 4.91 & 0.00 & 1.11 & 0.00 & 0.98 \\
\hline MSc Climate Change, Management, and Finance & 9.03 & 1.12 & 2.89 & 4.28 & 0.00 & 0.00 & 0.00 & 0.56 \\
\hline MSc Ecology, Evolution, and Conservation & 1.71 & 2.32 & 1.92 & 0.41 & 0.00 & 2.81 & 1.14 & 1.22 \\
\hline MSc Environmental Engineering & 1.56 & 0.30 & 3.78 & 0.86 & 0.00 & 2.47 & 0.35 & 0.76 \\
\hline MSc International Health Management & 0.14 & 0.36 & 3.75 & 1.31 & 1.61 & 1.03 & 0.00 & 2.68 \\
\hline MSc Sustainable Energy Futures & 3.26 & 3.41 & 3.09 & 2.79 & 0.12 & 1.91 & 0.00 & 0.35 \\
\hline MRes Bioengineering & 0.30 & 0.00 & 1.85 & 0.50 & 0.20 & 2.99 & 0.35 & 0.75 \\
\hline Mres Green Chemistry & 1.02 & 0.59 & 3.23 & 0.96 & 0.00 & 1.22 & 0.23 & 0.99 \\
\hline MSc Advanced Chemical Engineering & 1.49 & 0.29 & 2.21 & 0.82 & 0.00 & 2.35 & 0.34 & 0.72 \\
\hline MSc Advanced Computing & 1.25 & 0.00 & 3.41 & 0.00 & 0.00 & 2.04 & 0.29 & 0.62 \\
\hline MSc Applied Mathematics & 0.57 & 0.00 & 1.31 & 0.20 & 0.16 & 1.68 & 0.00 & 0.41 \\
\hline MSc Clinical Research & 0.91 & 0.45 & 3.36 & 1.42 & 1.23 & 0.97 & 0.45 & 1.88 \\
\hline MSc Finance and Accounting & 0.00 & 0.00 & 2.47 & 7.48 & 0.00 & 0.36 & 0.51 & 2.76 \\
\hline MSc Optics and Photonics & 0.55 & 0.00 & 2.09 & 0.00 & 0.00 & 0.80 & 0.00 & 0.25 \\
\hline MSc Petroleum Engineering & 1.73 & 0.00 & 2.35 & 0.52 & 0.00 & 2.30 & 0.26 & 0.78 \\
\hline MSc Science Communication & 0.00 & 0.89 & 3.30 & 2.54 & 0.00 & 2.29 & 0.00 & 1.27 \\
\hline
\end{tabular}

Scores from the application of the word codes for the eight attributes were higher in SOS for the more environmentally orientated programmes, e.g., Environmental Technology, Ecosystems and Environmental Change and Climate Change, Management, and Finance as expected. Sustainable Energy Futures had the highest score in JOS, followed by Ecology, Evolution, and Conservation, with all other courses generally showing zero or low scores of JOS, which is partly expected with Imperial considered a natural science and technology focused university. The highest scores for AEM were indeed for more financially and business-orientated programmes such as the one in Climate Change, Management, and Finance and the one in Finance and Accounting. Similarly, health orientated programmes, i.e., International Health Management and Clinical Research, showed highest values for HW coverage, while notably most of the other courses scored zero. For RSB and COL we expected that most programmes would aspire to develop problem-solving, collaboration, interdisciplinary, critical analysis, and ethical inquiry skills in their students, and indeed almost all programmes scored well for both, except for Climate Change, Management, and Finance that scored zero for COL. For DI we expected low scores in all courses, which was indeed the case, with seven of the courses scoring zero. Through the MCA method described above (see Supplementary Material Table S1 for details), the programmes were then ranked in terms of their overall alignment and contribution to sustainability (Figure 1). 


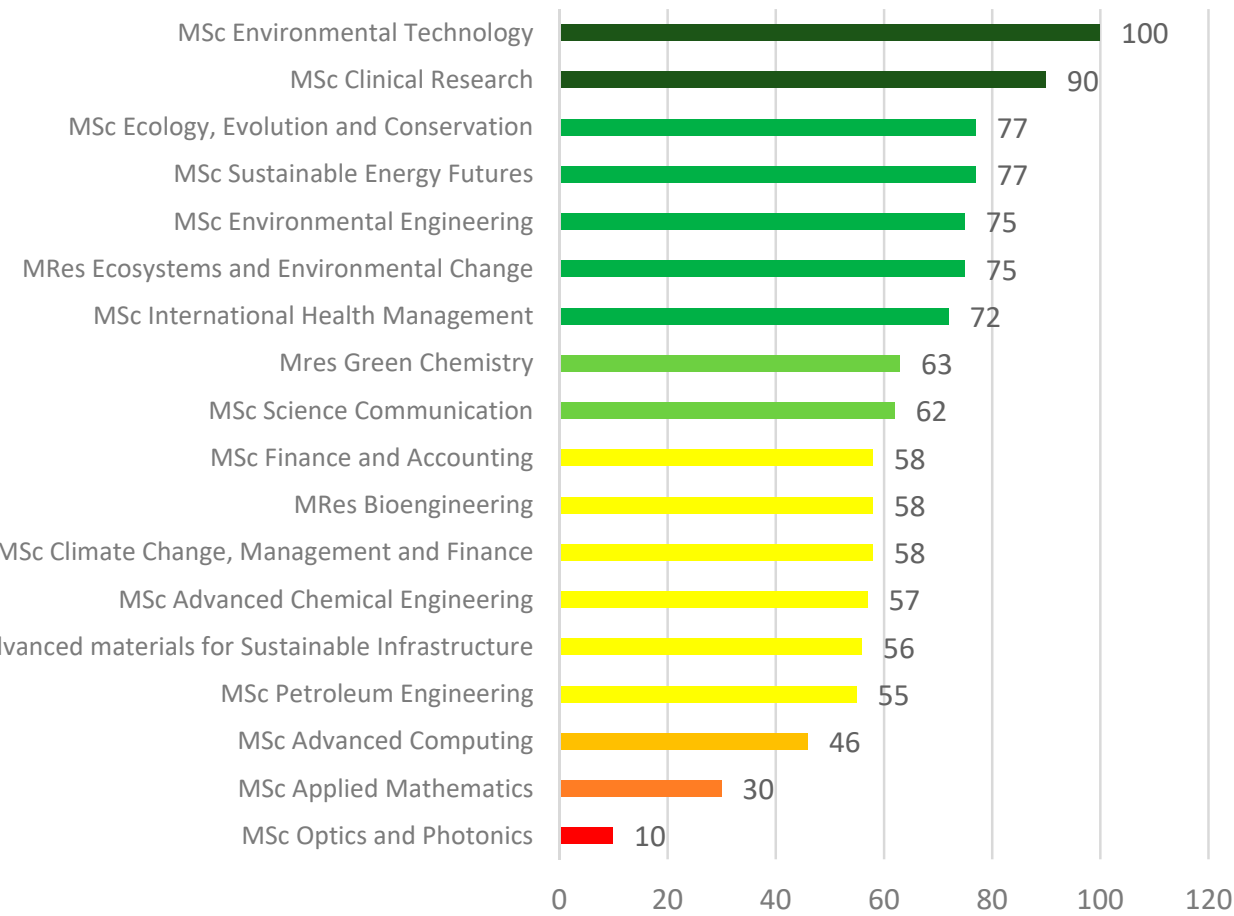

Figure 1. Ranking of 18 of Imperial College London master's courses through multicriteria analysis using the scores from the application of the word code developed for the eight sustainability attributes examined.

\subsection{Application}

Forty (40) well-established master's programmes related to environment and sustainability (35 offered by the UK and 5 by European universities) were evaluated using the methodology developed (Table 4). Each programme's LOs were compared against the word codes related to each sustainability attribute and were then ranked using MCA as described earlier.

Table 4. List of the MSc Programmes related to environment and sustainability evaluated in this study with links to the sources of their learning outcomes used in the assessment incorporated in their titles (accessed in June 2020).

\begin{tabular}{ccc}
\hline Code & Programme Title & University \\
\hline MScSTR & MSc Design Engineering with Sustainability & University of Strathclyde, Glasgow \\
\hline MScLVH & MSc Ecology \& Environmental Management & Liverpool Hope University \\
\hline MScCRN & MSc Environmental Engineering & Cranfield University \\
\hline MScNWC & MSc Environmental Engineering & Newcastle University \\
\hline MScBRN & MSc Environmental Management & Brunel University London \\
\hline MSCRDN & MSc Environmental Management & University of Reading \\
\hline MStCAM & MSt Sustainability Leadership & University of Cambridge \\
\hline MScSTM & MSc Sustainability & University of Southampton \\
\hline MScLDS & MSc Water Sanitation and Health Engineering & University of Leeds \\
\hline MScYRK & MSC Environmental Economics \& Environmental Management & University of York \\
\hline MasterETH & Master's in Environmental Sciences & ETH Zurich \\
\hline MasterWGU & Master's in Environmental Sciences & Wageningen University and Research \\
\hline MasterEPFL & Master's in Environmental Sciences \& Engineering & EPFL
\end{tabular}


Table 4. Cont.

\begin{tabular}{|c|c|c|}
\hline Code & Programme Title & University \\
\hline MasterLUN & Master's in Environmental Studies \& Sustainability Science & Lund University \\
\hline MPhilCAM & MPhil Environmental Policy & University of Cambridge \\
\hline MScUCL & MSc Environment \& Sustainable Development & University College London \\
\hline MScETICL & MSc Environmental Technology & Imperial College London \\
\hline MScMESPOM & MSc Environmental Science, Policy \& Management & Several * \\
\hline MScSUR & MSc Environmental Strategy & University of Surrey \\
\hline MScLIV & MSc Environmental Sciences & University of Liverpool \\
\hline MScBGM & MSc Environmental \& Natural Resource Economics & University of Birmingham \\
\hline MScNTG & MSc Environmental Leadership \& Management & University of Nottingham \\
\hline MScLBR & MSC Environmental Monitoring Research \& Management & Loughborough University \\
\hline MScBRS & MSc Environmental Policy \& Management & University of Bristol \\
\hline MScEDB & MSc Environmental Sustainability & The University of Edinburgh \\
\hline MScIESSTM & MSc Integrated Environmental Studies & University of Southampton \\
\hline MScEXT & MSc Mining Environmental Management & University of Exeter \\
\hline $\mathrm{MScCDF}$ & MSc Sustainability Planning \& Environmental Policy & Cardiff University \\
\hline MScSAN & MSc Sustainable Development & University of St Andrews \\
\hline MResICL & MRes Ecosystems \& Environmental Change & Imperial College London \\
\hline
\end{tabular}

* Lund University, the University of Manchester, Central European University, the University of the Aegean,

Middlebury Institute of International Studies at Monterey, and the University of Saskatchewan.

\section{Results}

The performance of the forty master's programmes across the eight sustainability attributes is presented in Table 5, and their ranking is based on their dominance scores from the pairwise comparison in Figure 2 (see Supplementary Materials for interpretations and calculations).

The programmes are ranked based on the alignment of their LOs to sustainability with their dominance score calculated based on the number of times each programme performed better than the others for each given attribute. Although most of the programmes examined in this study showed high coverage of SOS, which is reasonable as they are environment and sustainability orientated, most did not seem to adequately cover DI and HW, both important aspects of sustainability.

Table 5. Performance of the forty environment and sustainability related master's courses from UK and European universities across the eight sustainability attributes based on the word codes.

\begin{tabular}{ccccccccc}
\hline Master's Programmes & SOS & JOS & RSB & AEM & HW & COL & DI & TG \\
\hline MScSTR & 0.76 & 0.09 & 4.00 & 4.16 & 0.52 & 0.18 & 0.10 & 0.68 \\
MScLVH & 5.17 & 0.29 & 5.21 & 0.21 & 0.00 & 0.67 & 1.00 & 1.17 \\
MScCRN & 6.24 & 1.58 & 3.97 & 3.47 & 0.13 & 0.23 & 0.22 & 0.41 \\
MScNWC & 5.63 & 2.15 & 2.22 & 0.95 & 0.71 & 0.00 & 0.00 & 0.41 \\
MScBRN & 8.88 & 1.81 & 3.26 & 2.74 & 0.61 & 0.00 & 0.00 & 1.36 \\
MScRDN & 4.90 & 1.61 & 2.82 & 0.96 & 1.27 & 2.02 & 0.22 & 1.40 \\
MStCAM & 3.12 & 2.98 & 9.29 & 2.69 & 0.32 & 1.27 & 0.21 & 5.24 \\
\hline
\end{tabular}


Table 5. Cont.

\begin{tabular}{|c|c|c|c|c|c|c|c|c|}
\hline Master's Programmes & SOS & JOS & RSB & AEM & HW & COL & DI & TG \\
\hline MScSTM & 2.59 & 1.45 & 3.19 & 0.45 & 0.55 & 0.91 & 0.38 & 0.30 \\
\hline MScLDS & 2.06 & 2.43 & 4.82 & 1.77 & 1.85 & 0.48 & 0.11 & 1.55 \\
\hline MScYRK & 7.27 & 1.91 & 3.36 & 1.05 & 0.17 & 0.44 & 0.78 & 1.69 \\
\hline MasterETH & 5.89 & 1.41 & 3.40 & 1.14 & 0.58 & 0.00 & 0.46 & 1.02 \\
\hline MasterWGU & 4.75 & 1.53 & 3.63 & 0.40 & 0.63 & 1.31 & 0.31 & 1.32 \\
\hline MasterEPFL & 13.99 & 2.54 & 1.43 & 0.00 & 0.00 & 2.70 & 0.00 & 0.00 \\
\hline MasterLUN & 5.31 & 2.69 & 8.79 & 0.52 & 1.05 & 1.18 & 0.00 & 0.66 \\
\hline MPhilCAM & 0.58 & 0.27 & 6.77 & 0.81 & 0.58 & 1.66 & 0.00 & 0.49 \\
\hline MScLAN & 3.91 & 2.38 & 2.05 & 1.10 & 0.34 & 0.30 & 0.56 & 1.38 \\
\hline MScUCL & 8.00 & 8.12 & 5.76 & 0.94 & 0.00 & 0.00 & 0.00 & 1.06 \\
\hline MScETICL & 4.78 & 1.24 & 5.87 & 1.12 & 0.31 & 1.65 & 0.12 & 1.87 \\
\hline MScOXF & 12.01 & 2.53 & 8.06 & 0.63 & 0.63 & 1.82 & 0.00 & 1.03 \\
\hline MScMESPOM & 8.94 & 0.64 & 7.32 & 0.98 & 0.20 & 3.69 & 0.64 & 2.46 \\
\hline MScSUR & 7.37 & 1.11 & 7.22 & 1.45 & 1.28 & 0.37 & 0.00 & 2.09 \\
\hline MScLIV & 4.61 & 1.06 & 2.65 & 0.29 & 0.14 & 2.54 & 0.48 & 1.53 \\
\hline MScBGM & 1.93 & 0.74 & 0.99 & 1.80 & 0.26 & 0.00 & 0.22 & 3.17 \\
\hline MScLSE & 9.90 & 0.00 & 2.51 & 3.55 & 0.59 & 2.51 & 0.00 & 4.14 \\
\hline MScUBA & 5.44 & 1.21 & 4.18 & 2.70 & 0.54 & 1.11 & 0.13 & 1.19 \\
\hline MScMAN & 5.86 & 0.84 & 4.04 & 0.28 & 0.46 & 0.84 & 0.16 & 2.37 \\
\hline MScNTG & 8.55 & 0.91 & 8.87 & 0.54 & 0.86 & 0.70 & 0.22 & 3.76 \\
\hline MScLBR & 4.74 & 0.54 & 1.68 & 0.19 & 0.14 & 0.60 & 0.14 & 0.77 \\
\hline MScBRS & 4.94 & 0.90 & 3.71 & 0.41 & 0.51 & 1.19 & 0.29 & 1.60 \\
\hline MScEDB & 7.02 & 1.89 & 4.00 & 1.19 & 0.87 & 1.16 & 0.34 & 2.15 \\
\hline MScIESSTM & 3.47 & 1.36 & 2.65 & 0.36 & 0.26 & 0.97 & 0.23 & 0.37 \\
\hline MScEXT & 3.21 & 1.46 & 2.72 & 1.05 & 0.04 & 0.69 & 0.04 & 1.93 \\
\hline $\mathrm{MScCDF}$ & 6.33 & 2.36 & 4.27 & 1.09 & 0.17 & 0.00 & 0.19 & 2.66 \\
\hline MScSAN & 0.74 & 3.20 & 11.88 & 0.62 & 2.77 & 0.68 & 0.00 & 3.63 \\
\hline MResICL & 3.66 & 0.38 & 2.25 & 0.38 & 0.00 & 2.14 & 0.42 & 2.79 \\
\hline MScAMSIICL & 2.16 & 0.39 & 2.03 & 4.91 & 0.00 & 1.11 & 0.00 & 0.98 \\
\hline MScCCMFICL & 9.03 & 1.12 & 2.89 & 4.28 & 0.00 & 0.00 & 0.00 & 0.56 \\
\hline MScEECICL & 1.71 & 2.32 & 1.92 & 0.41 & 0.00 & 2.81 & 1.14 & 1.22 \\
\hline MScEEICL & 1.56 & 0.30 & 3.78 & 0.86 & 0.00 & 2.47 & 0.35 & 0.76 \\
\hline MScSEFICL & 3.26 & 3.41 & 3.09 & 2.79 & 0.12 & 1.91 & 0.00 & 0.35 \\
\hline
\end{tabular}

Diversity, Equality, and Inclusion, specifically in the UK context, are being promoted through Advance HE's Race and Gender Equality charters as pillars that can lead to sustainable social change. Health and Wellbeing, apart from being a stand-alone SDG (SDG3), is an important dimension of the academic environment that should be safeguarded and further highlighted, as it links not only with increased productivity but is also an important research area. Both DI and HW, which are underrepresented in the programmes considered, are the ultimate ends of SD according to the Daly Triangle, which provides an integrating framework for selecting overarching goals for sustainability interventions [51].

Out of the top 10 programmes, 8 scored highly across all sustainability attributes. These are Environmental Sustainability EDB, Sustainability Leadership CAM, MESPOM, Environmental Leadership and Management NTG, Environmental Economics and Management YRK, Water Sanitation and Health Engineering LDS, Environmental Management RDN, and Environmental Technology ICL. The remaining 2, Environmental Change and Management OXF and Environmental Strategy SUR scored strongly in SOS and RSB but zero in DI. With respect to the performance of their LOs' alignment to sustainability, they are either related to sustainability and leadership or are focusing on environment and management, economics, and engineering and thus show integration between different areas of study. The same applies for the European master's programmes: the ones that show integration of different disciplines rank highly, with MESPOM being first of the five European programmes and third in the overall ranking. MESPOM is an inter-university programme allowing students to study in four 
different countries and become exposed to scientific, technological, socio-environmental, and political aspects of environmental change, unique to each location. In terms of LOs, it differentiates between knowledge and understanding, skills, values, and attitudes, which is more conducive to sustainability competences definition. MSc Sustainability Leadership CAM is a course using a workshop format to cover very diverse aspects of sustainability such as business, finance, governance, behaviour, leadership, collaboration, and partnerships, apart from the main socio-environmental aspects. MSc Environmental Sustainability EDB stresses the interdisciplinary nature of SD and allows students to study the interactions between science, policy, business, and governance to address sustainability problems. It provides insights into behavioural and ethical aspects of sustainability as well and integrates modules that range from ecology to climate change and politics through general and module specific LOs. In general, these programmes employ a systemic and interdisciplinary approach to addressing SD across scales and paradigms that includes its ethical implications, which require critical analysis and the development of sustainability competences. Although these programmes are performing better than most of the others analysed here, there is still a lot of room for improvement and all would benefit from recording their gaps and trying to achieve a more balanced representation of the sustainability attributes in their LOs.

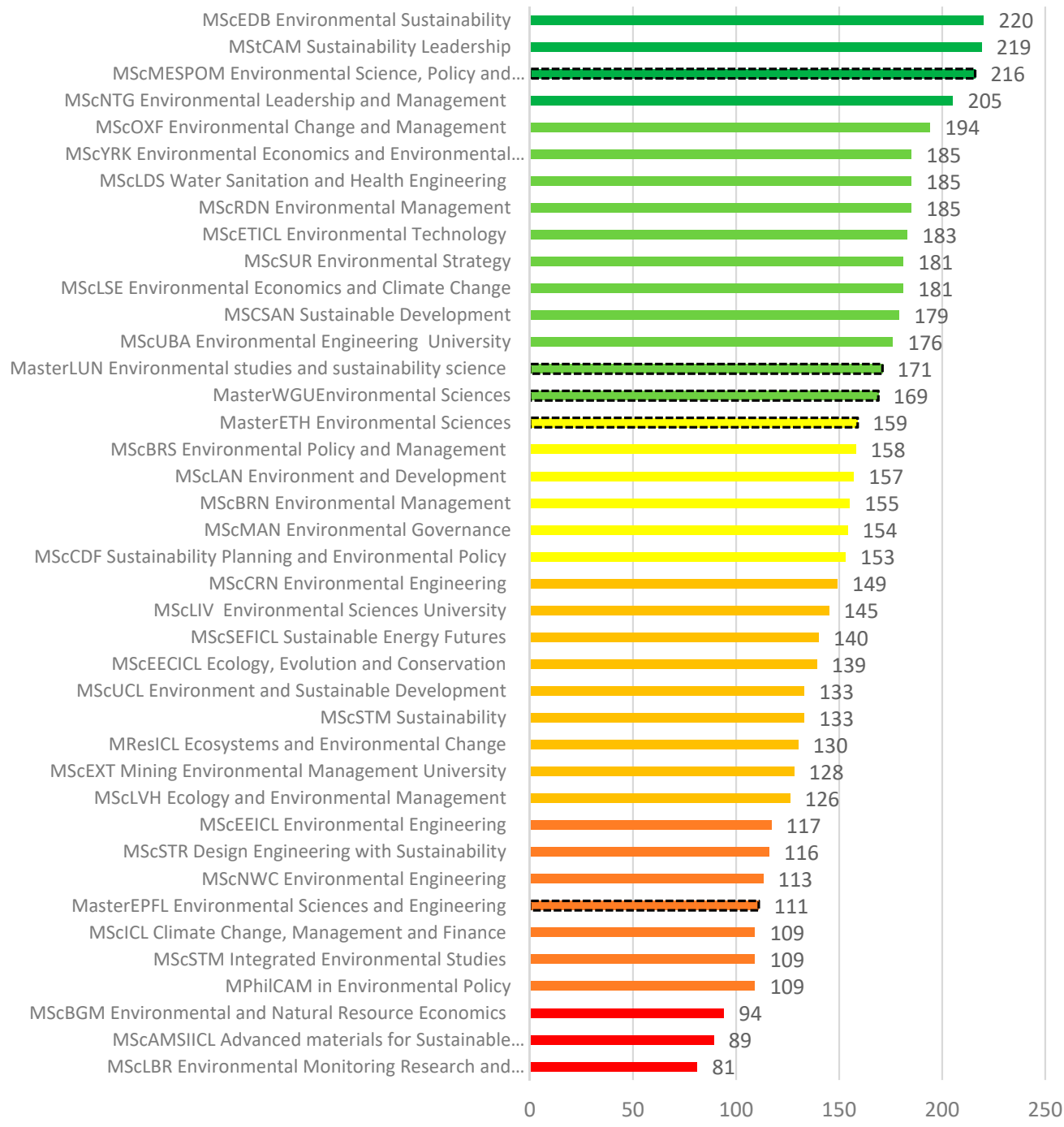

Figure 2. Dominance scores and ranking of forty environment and sustainability related master's Programmes in terms of their contribution to sustainability, based on the alignment of their learning outcomes to key sustainability attributes (the dashed bars represent European master's courses). 
Most of the programmes at the bottom of the rank had scored zero in at least one sustainability attribute, with one programme scoring zero in four. Often the attributes with the lowest scores are in decreasing order, in DI, HW, COL, TG, and AEM. In terms of their relationship with sustainability, most are related to environmental aspects such as policy, management, or engineering, one is specifically related to materials for sustainability, and another one is related to climate change and finance. In general, these programmes would benefit from incorporating more aspects of sustainability in their LOs, such as JOS, COL, DI, HW, TG, and AEM, and articulating more specific LOs relating to those aspects.

Comparison of master's programmes that include the same topics in their titles, such as those related to environmental management ( 9 courses), environmental engineering ( 5 courses), and environmental science ( 5 courses), show that they do not necessarily score in all (or the same) sustainability attributes. Zero scores were observed in COL, TG, DI, and HW, and programmes place different emphasis on JOS (moderate to low) and AEM (moderate to low). Surprisingly, a few programmes that include the topic sustainability or sustainable development in their titles score zero in the HW, DI, and COL and show substantial variation in their scores for SOS, AEM, and JOS (low to high).

Comparing programmes offered by the same Institution (such as University of Cambridge, University of Southampton, and Imperial College London) shows that there can be large (CAM 25\%), intermediate (ICL 11\%), or small differences (STM 3\%) in the scoring on sustainability attributes between courses.

Almost $82.5 \%$ of the master's programmes' overall ranking values are between 100 and 200, although some outliers are noted: 3 courses score below 100 and 4 courses above 200. Our overall values distribution approximates a normal distribution (Shapiro Wilks test: sig. $=0.510, \mathrm{dF}=40$, statistic $=0.975 ;$ kurtosis $=0.59$, skewness $=-0.764)$. The mean $(151.4)$ and median values $(153.5)$ show that most programmes have values around 152. One important observation from the graph is that there are some pairs of programmes that show very similar scores, for example, Sustainability Leadership CAM with Environmental Sustainability EDB, Environmental Economics and Climate Change LSE with Environmental Strategy SUR, Environment Management RDN with Water Sanitation and Health Engineering LDS and Environmental Economics and Environmental Management YRK, and Environment and Sustainable Development UCL with Sustainability STM. This indicates that when designing a course (from the offeror's perspective) or selecting a course to attend (from the student's perspective), reviewing the programme's LOs is important, as there seems to be no link between course names and scores. For the academic staff responsible for the programmes, understanding the scores per attribute is important, as it can help them redefine their module's intended LOs or their selected competencies, map the gaps in covering various aspects of sustainability, understand in which areas they place more focus, and refine their programmes' descriptors by reforming some of their curricular content.

\section{Discussion}

The assessment tool developed here offers the first step in a process that will allow HE practitioners to evaluate and improve their educational offerings, increasing their sustainability contribution. Reviewing academic programmes' intended LOs, the tool evaluates how well "what the students are going to achieve at the end of the programme" aligns with sustainability attributes and with the enabling conditions for the emergence of sustainability. Courses are evaluated in what they aspire to deliver, rather than how effective they are in their delivery. This is important as teaching context, learning activities, and assessments are designed on the basis of these learning outcomes. LOs will drive the pedagogical approach and the teaching practices to achieve them. Relating LOs to sustainability and defining the knowledge, skills, behaviours, and attitudes that learners will need to develop through the course will shape their contribution to sustainability. For this contribution to become realised, the next step will be their implementation and assessment, collecting the evidence 
that these outcomes are delivered in practice. Ensuring that LOs are sustainability related will not guarantee that university graduates attain those traits. Assessment of competence development or mastery of the LOs related to sustainability will allow practitioners to understand how effective their approach is.

The tool can support HE practitioners to make data-driven decisions and modifications in their programmes to improve alignment to sustainability. Different courses delivered by the same institution or courses in the same subject but delivered by different institutions can be compared and ranked. This can help programmes that have a similar orientation to identify similarities and differences between them and make appropriate adaptations. Furthermore, comparisons can extend to different geographies such that the priorities, gaps, commonalities, and differences of HE curricula for SD can be highlighted across continents [52]. This in turn will assist the engagement of on- and off-campus ESD stakeholders, the formation of collaborations between universities and the local communities, and also the realisation that $\mathrm{SD}$ is equally about its environmental pillar as well as its social and economic ones and should be seen as an integrated concept [53].

Another benefit that the methodology presented in this study specifically offers to MSc programmes' coordinators, curriculum developers, and lecturers is that it allows them to be more systematic in articulating LOs for sustainability and also more systemic as they will be able to target sustainability comprehensively. Apart from mapping coverage of attributes and understanding how their programmes relate to sustainability and make improvements by addressing gaps and balancing all aspects of sustainability, they can also design their LOs in a more integrated and systematic way.

From our review of programme descriptors, there are programmes that mention general programme LOs and others that provide LOs for each programme module. With respect to the first group, some mention what the students will gain from studying in the programme, while others provide LOs divided into categories such as knowledge and understanding, skills, attitudes, and values. The second group either: (a) describe briefly the content of each module and student gains, (b) describe the content or aim of each module and list LOs, or (c) describe content, aim, teaching and assessment methods, and LOs. The latter either mention only lists of LOs without differentiation, or a breakdown of LOs into knowledge and understanding and skills, such as intellectual, practical, professional, employability, and transferable. Others may mention specific professional competences or graduate attributes. However, we propose that being more specific with stating intended LOs for both the whole programme and for each module is clearer and more useful, as it can lead to better teaching methods and also measurable assessment formats to be implemented [53,54]. Last but not least, breakdown of LOs into knowledge, skills, and values or use of competences also contributes to better course outcomes $[20,55]$.

The methodology developed here, when embedded in existing sustainability assessment tools in HE such as the Sustainability Tracking, Assessment \& Rating System (STARs) for HE Institutions, can offer benchmarking in terms of evaluating progress toward the SDGs across institutions and geographies [56]. It will highlight similarities and differences as well as gaps in the integration of the SDGs in their LOs and also allow for a more uniform and thus comparable design of LOs across educational systems. Currently, sustainability assessment and reporting tools for HE Institutions focus mainly on the number of sustainability-related courses, the integration of sustainability themes in current courses, the pedagogical methods used to teach sustainability, educator training courses, and SD definitions within the curriculum, but they do not examine the courses' LOs' relationship to sustainability [57].

We expect courses that are advanced in their sustainability offerings and have developed their own vision of a sustainable society to also use our methodology and adapt it to reflect the sustainability attributes they have selected. However, they can also compare their criteria to the ones presented in this paper and draw conclusions about which aspects of sustainability they cover most or least and make changes. University course coordinators, curriculum planners, and other relevant stakeholders who aim to integrate the SDGs in their courses can do so by aligning their course's LO with the SDGs 
in the systemic way we presented. This will enable them to develop relevant pedagogies, learning activities, and assessment modes to enhance the development of sustainability competences in their learners [58].

A recent systematic literature review on the evolution of the concept of sustainability in the educational field with emphasis on HE shows similar results [7]. Specifically, it highlights the environmental orientation of ESD in its first years, with special emphasis on biodiversity issues that later evolved to include socio-cultural, ethical, behavioural, governance, and health dimensions. This shows a transition to more holistic views of ESD that, although present in the literature about how ESD curricula, teaching, and learning approaches should be designed, is not found in practice.

\section{Limitations of the Study}

As limitations of this study, we can mention that the developed word codes might not be comprehensive in reflecting the diversity of concepts encompassed in the sustainability attributes used, although we tried to overcome this by using relevant and accurate scientific publications. Furthermore, we tried to make the word codes appropriate for educational purposes so that important terms are captured in the analysed courses' LOs. This was done by use of the QAA benchmark statements and the ECU guiding documents for implementing diversity and inclusion in HE curricula, which add to the validity of the method, as they constitute the accepted standard for designing HE programmes in the UK. Lastly, we excluded words from the word code that may be ambiguous in terms of acquiring different meanings according to context.

Supplementary Materials: The following are available online at http://www.mdpi.com/2071-1050/12/17/6701/s1: Table S1: Pairwise comparisons between the 18 Imperial College master's programmes' LOs total performance on the eight sustainability attributes. The table reports their positive or zero dominance scores, Table S2: Pairwise comparisons between the 40 environment and sustainability related master's programmes' LOs total performance on the eight sustainability attributes, Interpretation of Table 5 results.

Author Contributions: V.K. and N.V. conceived, wrote, and reviewed the research article. All authors have read and agreed to the published version of the manuscript.

Funding: V.K. was funded by the Imperial College President's PhD Scholarships.

Acknowledgments: The authors wish to thank Ans Vercammen, Research Fellow at the Centre for Environmental Policy of Imperial College London, for reviewing the manuscript and providing useful suggestions and the reviewers of Sustainability Journal for their helpful comments aiming to improve the quality of the manuscript.

Conflicts of Interest: The authors declare no conflict of interest.

\section{References}

1. UNICEF; The World Bank; UNFPA; UNDP; UN Women; UNHCR. Education 2030_Incheon Declaration and Framework for Action-Ensure Inclusive and Equitable Quality Education and Promote Lifelong Learning Opportunities for All; UNESCO: Paris, France, 2016; Available online: http://unesdoc.unesco.org/images/0024/ 002456/245656E.pdf (accessed on 17 August 2020).

2. Australia/Pacific SDSN. Getting Started with the SDGS in Universities: A Guide for Universities, Higher Education Institutions, and the Academic Sector; Australia/Pacific SDSN: Melbourne, Australia, 2017.

3. Ottersen, O.P. Modernising Higher Education in the Agenda 2030 era. In Proceedings of the Rethinking Higher Education Inspired by the Sustainable Development Goals, Solna, Sweden, 30 March 2019.

4. Times Higher Education World University Rankings (2019). Impact Rankings. Available online: https://www.timeshighereducation.com/rankings/impact/2019/overall\#!/page/0/length/25/sort_by/rank/ sort_order/asc/cols/undefined (accessed on 18 June 2020).

5. UNESCO. UNESCO Moving forward the 2030 Agenda for Sustainable Development; UNESCO: Paris, France, 2017; Available online: https://sustainabledevelopment.un.org/content/documents/21252030\%20Agenda\% 20for\%20Sustainable\%20Development\%20web.pdf (accessed on 17 August 2020).

6. O'Byrne, D.; Dripps, W.; Nicholas, K.A. Teaching and learning sustainability: An assessment of the curriculum content and structure of sustainability degree programs in higher education. Sustain. Sci. 2015, 10, 43-59. [CrossRef] 
7. Perera, C.R.; Hewege, C.R. Integrating sustainability education into international marketing curricula. Int. J. Sustain. High Educ. 2016, 17, 123-148. [CrossRef]

8. Rodríguez-García, A.-M.; López Belmonte, J.; Agreda Montoro, M.; Moreno-Guerrero, A.-J. Productive, structural and dynamic study of the concept of sustainability in the educational field. Sustainability 2019, 11, 5613. [CrossRef]

9. Vincent, S.; Bunn, S.; Stevens, S. Sustainability Education: Results from the 2012 Census of US Four Year Colleges and Universities; National Council for Science and Education: Washington, DC, USA, 2013; Available online: https://scholar.google.ca/scholar?hl=en\&q=Sustainability+education: +results+from +the+2012+census+of+U.S.+Four+Year+Colleges+and+Universities.+National+Council+ for + Science+and+Education\&btnG=\&as_sdt=1,5\&as_sdtp=\#0 (accessed on 17 August 2020).

10. EAUC; National Union of Students; UCU; Association of Colleges; The College Development Network. Sustainability in Education 2018-2019; National Union of Students: London, UK, 30 March 2019; Available online: https://sustainability.nus.org.uk/resources/sustainability-in-education-2018-research-report (accessed on 17 August 2020).

11. Zamora-Polo, F.; Sánchez-Martín, J.; Corrales-Serrano, M.; Espejo-Antúnez, L. What do university students know about sustainable development goals? A realistic approach to the reception of this UN program amongst the youth population. Sustainability 2019, 11, 3533. [CrossRef]

12. Fuertes-Camacho, M.T.; Graell-Martín, M.; Fuentes-Loss, M.; Balaguer-Fàbregas, M.C. Integrating sustainability into higher education curricula through the project method, a global learning strategy. Sustainability 2019, 11, 767. [CrossRef]

13. Quality Assurance Agency; Higher Education Academy. Education for Sustainable Development-Guidance for UK HE Providers. June 2014. Available online: https://www.qaa.ac.uk/docs/qaa/quality-code/educationsustainable-development-guidance-june-14.pdf?sfvrsn=1c46f981_8 (accessed on 17 August 2020).

14. Sherren, K. Core issues: Reflections on sustainability in Australian University coursework programs. Int. J. Sustain. High. Educ. 2006, 7, 400-413. [CrossRef]

15. Sherren, K. Balancing the disciplines: A multidisciplinary perspective on sustainability curriculum content. Aust. J. Environ. Educ. 2005, 21, 97-106. [CrossRef]

16. Sherren, K. Higher environmental education: Core disciplines and the transition to sustainability the transition to sustainability. Australas. J. Environ. Manag. 2008, 15, 189-196. [CrossRef]

17. Segalàs, J.; Ferrer-Balas, D.; Mulder, K.F. What do engineering students learn in sustainability courses? The effect of the pedagogical approach. J. Clean. Prod. 2010, 18, 275-284. [CrossRef]

18. Iyer-Raniga, U.; Andamon, M.M. Transformative learning: Innovating sustainability education in built environment. Int. J. Sustain. High. Educ. 2016, 17, 105-122. [CrossRef]

19. Leal Filho, W.; Shiel, C.; Paço, A.; Mifsud, M.; Ávila, L.V.; Brandli, L.L.; Molthan-Hill, P.; Pace, P.; Azeiteiro, U.M.; Vargas, V.R.; et al. Sustainable development goals and sustainability teaching at universities: Falling behind or getting ahead of the pack? J. Clean. Prod. 2019, 232, 285-294. [CrossRef]

20. Kioupi, V.; Voulvoulis, N. Education for sustainable development: A systemic framework for connecting the SDGs to educational outcomes. Sustainability 2019, 11, 6104. [CrossRef]

21. Part B: Ensuring and Enhancing Academic Quality, Chapter B3: Learning and Teaching. In UK Quality Code for Higher Education; The Quality Assurance Agency for Higher Education: Gloucester, UK, 2018.

22. Rockström, J.; Steffen, W.; Noone, K.; Persson, Å.; Chapin, F.S.; Lambin, E.; Lenton, T.M.; Scheffer, M.; Folke, C.; Schellnhuber, H.J.; et al. Planetary boundaries: Exploring the safe operating space for humanity. Ecol. Soc. 2009, 14, 32. [CrossRef]

23. Steffen, W.; Richardson, K.; Rockström, J.; Cornell, S.E.; Fetzer, I.; Bennett, E.M.; Biggs, R.; Carpenter, S.R.; De Vries, W.; De Wit, C.A.; et al. Planetary boundaries: Guiding changing planet. Science 2015, 347, 1259855. [CrossRef] [PubMed]

24. Raworth, K. A Safe and Just Space for Humanity-Can We Live Inside the Doughnut? Why the World Needs Planetary and Social Boundaries; Oxfam Great Britain: Cowley, UK, 2012; pp. 1-26. Available online: https://www-cdn.oxfam.org/s3fs-public/file_attachments/dp-a-safe-and-just-space-forhumanity-130212-en_5.pdf (accessed on 17 August 2020).

25. Dearing, J.A.; Wang, R.; Zhang, K.; Dyke, J.G.; Haberl, H.; Hossain, M.S.; Langdon, P.G.; Lenton, T.M.; Raworth, K.; Brown, S.; et al. Safe and just operating spaces for regional social-ecological systems. Glob. Environ. Chang. 2014, 28, 227-238. [CrossRef] 
26. Giovannoni, E.; Fabietti, G. What is sustainability? A review of concept and its applications. In Integrated Report Concepts and Cases that Redefine Corporate Accountability; Springer International Publishing: Cham, Switzerland, 2013; pp. 21-40.

27. Komasinkski, A.; Ishimura, G. Critical thinking and normative competencies for sustainability science education. J. High. Educ. Lifelong Learn. 2017, 24, 21-37.

28. Barth, M.; Godemann, J.; Rieckmann, M.; Stoltenberg, U. Developing key competencies for sustainable development in higher education. Int. J. Sustain. High. Educ. 2007, 8, 416-430. [CrossRef]

29. Blok, V.; Gremmen, B.; Wesselink, R. Dealing with the 'wicked problem' of sustainability: The role of individual virtuous competence. Bus. Prof. Ethics J. 2016, 34, 297-327. [CrossRef]

30. Schank, C.; Rieckmann, M. Socio-economically substantiated education for sustainable development: Development of competencies and value orientations between individual responsibility and structural transformation. J. Educ. Sustain. Dev. 2019, 13, 67-91. [CrossRef]

31. Remington-Doucette, S.M.; Connell, K.Y.H.; Armstrong, C.M.; Musgrove, S.L. Assessing sustainability education in a transdisciplinary undergraduate course focused on real-world problem solving: A case for disciplinary grounding. Int. J. Sustain. High. Educ. 2013, 14, 404-433. [CrossRef]

32. Davis, T.; Hennes, E.P.; Raymond, L. Cultural evolution of normative motivations for sustainable behaviour. Nat. Sustain. 2018, 1, 218-224. [CrossRef]

33. Costanza, R.; Daly, L.; Fioramonti, L.; Giovannini, E.; Kubiszewski, I.; Mortensen, L.F.; Pickett, K.E.; Ragnarsdottir, K.V.; De Vogli, R.; Wilkinson, R. Modelling and measuring sustainable wellbeing in connection with the UN Sustainable Development Goals. Ecol. Econ. 2016, 130, 350-355. [CrossRef]

34. Cook, J.W. Sustainability, Human Well-Being, and the Future of Education; Springer Nature Switzerland AG: Cham, Switzerland, 2018.

35. Hinchliffe, S.; Jackson, M.A.; Wyatt, K.; Barlow, A.E.; Barreto, M.; Clare, L.; Depledge, M.; Durie, R.; Fleming, L.E.; Groom, N.; et al. Healthy publics: Enabling cultures and environments for health. Palgrave Commun. 2018, 4, 1-10. [CrossRef] [PubMed]

36. Barrington-Leigh, C. Sustainability and well-being: A happy synergy. Development 2016, 59, 292-298. [CrossRef]

37. Kjaer, L.L.; Pigosso, D.C.A.; Niero, M.; Bech, N.M.; McAloone, T.C. Product/service-systems for a circular economy: The route to decoupling economic growth from resource consumption? J. Ind. Ecol. 2019, 23, 22-35. [CrossRef]

38. Sterling, E.J.; Filardi, C.; Toomey, A.; Sigouin, A.; Betley, E.; Gazit, N.; Newell, J.; Albert, S.; Alvira, D.; Bergamini, N.; et al. Biocultural approaches to well-being and sustainability indicators across scales. Nat. Ecol. Evol. 2017, 1, 1798-1806. [CrossRef]

39. Fath, B.D.; Fiscus, D.A.; Goerner, S.J.; Berea, A.; Ulanowicz, R.E. Measuring regenerative economics: 10 principles and measures undergirding systemic economic health. Glob. Transit. 2019, 1, 15-27. [CrossRef]

40. Macarthur, E. Towards a circular economy. J. Ind. Ecol. 2012, 2, $23-44$.

41. The Ellen MacArthur Foundation, Foundation EM. Towards a Circular Economy: Business Rationale for an Accelerated Transition. Greener Manag. Int. 2015, 97, 20.

42. Guo, S.; Jamal, Z. Nurturing cultural diversity in higher education: A critical review of selected models. Can. J. High. Educ. 2007, 37, 27-49.

43. WWF. Living Planet Report 2018: Aiming Higher; Grooten, M., Almond, R.E.A., Eds.; WWF: Gland, Switzerland, 2018; p. 148.

44. FAO Commission on Genetic Resources for Food and Agriculture. The State of the World's Biodiversity for Food and Agriculture; Pilling, D., Bélanger, J., Eds.; FAO Commission on Genetic Resources for Food and Agriculture Assessments: Rome, Italy, 2019; p. 572.

45. Díaz, S.; Settele, J.; Brondízio, E. Report of the plenary of the intergovernmental science-policy platform on biodiversity and ecosystem services on the work of its seventh session. In Proceedings of the Intergovernmental Science-Policy Platform on Biodiversity and Ecosystem Services (IPBES), Paris, France, 29 April-4 May 2019; Volume 7.

46. ECU Gender Charter Athena SWAN. Gender Equality; ECU Equality Challenge Unit: London, UK, 2017.

47. Equality Challenge Unit. ECU Race Equality Charter Handbook; ECU: London, UK, 2016; p. 56. 
48. Equality Challenge Unit, Higher Education Academy Scotland. Papers from Equality Challenge Unit and Higher Education Academy Joint Conferences, Scotland. 2016, p. 142. Available online: https://s3.eu-west-2.amazonaws.com/assets.creode.advancehe-document-manager/ documents/ecu/Equality-and-diversity-in-learning-and-teaching-Full-report_1573211251.pdf (accessed on 17 August 2020).

49. Saaty, R.W. The analytic hierarchy process-What it is and how it is used. Math. Model. 1987, 9, 161-176. [CrossRef]

50. Department for Communities and Local Government. Multicriteria Analysis-A Manual; Department for Communities and Local Government: London, UK, 2009; p. 165. Available online: http://eprints.lse.ac.uk/ 12761/1/Multi-criteria_Analysis.pdf (accessed on 17 August 2020).

51. Meadows, D. Indicators and Information Systems for Sustainable by Donella Meadows. A Report to the Balaton Group; The Sustainability Institute: Stellenbosch, South Africa, 1998; Volume 78, Available online: http://donellameadows.org/wp-content/userfiles/IndicatorsInformation.pdf (accessed on 17 August 2020).

52. Franco, I.; Saito, O.; Vaughter, P.; Whereat, J.; Kanie, N.; Takemoto, K. Higher education for sustainable development: Actioning the global goals in policy, curriculum and practice. Sustain. Sci. 2018, 14, 1621-1642. [CrossRef]

53. Casey, K.; Sturgis, C. Levers and Logic Models: A Framework to Guide Research and Design of High-Quality Competency-Based Education Systems. 2018, Volume 55. Available online: https:/www.competencyworks.org/wp-content/uploads/2018/05/CompetencyWorksLevers-and-Logic-Models.pdf (accessed on 17 August 2020).

54. Chun, M. Taking teaching to (performance) task: Linking pedagogical and assessment practices. Chang. Mag. High. Learn. 2010, 42, 22-29. [CrossRef]

55. Shephard, K.; Harraway, J.; Lovelock, B.; Mirosa, M.; Skeaff, S.; Slooten, L.; Strack, M.; Furnari, M.; Jowett, T.; Deaker, L.; et al. Seeking learning outcomes appropriate for 'education for sustainable development' and for higher education. Assess. Eval. High. Educ. 2015, 40, 855-866. [CrossRef]

56. Lidstone, L.; Wright, T.; Sherren, K. An analysis of Canadian STARS-rated higher education sustainability policies. Environ. Dev. Sustain. 2015, 17, 259-278. [CrossRef]

57. Ceulemans, K.; Molderez, I.; Van Liedekerke, L. Sustainability reporting in higher education: A comprehensive review of the recent literature and paths for further research. J. Clean. Prod. 2015, 106, 127-143. [CrossRef]

58. Evans, T.L. Competencies and pedagogies for sustainability education: A roadmap for sustainability studies program development in colleges and universities. Sustainability 2019, 11, 5526. [CrossRef] 